\title{
ПОТУЖНА ПРАГМАТИКА «МАЛЕНЬКИХ СЛІВ»
}

(Космеда Т., Олексенко О., Павлова І. Семантика й прагматика дискурсивного слова та його потенціал для діагностики психотипу мовної особистості: аспектуальний опис: монографія. За наук. ред. проф. Т. Космеди. Харків: Харківське історико-філологічне товариство, 2019. 308 с.)

Широке сучасне розуміння поняття дискурсу вмотивовує й різноаспектну палітру його опису. Монографія авторства Т. Космеди, О. Олексенко, І. Павлової - результат багаторічних наукових спостережень, фрагментарних досліджень, апробацій, що вилилися в грунтовне, монолітне видання, яке презентує дискурс «як складне лінгвістичне явище, що виникає на грунті упорядкування випадкового, пов'язаного з особою чи групою осіб мовлення, та стабільного, усталеного, пов'язаного із традицією, історією, ментальністю, усталеними стереотипами» (Космеда, Олексенко \& Павлова, 2019: 14-15).

У рецензованій праці презентовано новий напрям сучасної лінгвістики - дискурслінгвістику, висвітлено конститутивні засади теорії дискурсивного слова та описано специфіку функціювання дискурсивних слів (ДС) у різних видах українського дискурсу. Автори грунтують свій доробок на постулатах класичної лінгвістики (О. Потебня, Л. Булаховський, І. Франко, Ю. Шевельов, Л. Щерба), ураховуючи новітні напрацювання українського (Ф. Бацевич, А. Загнітко, М. Степаненко) й зарубіжного мовознавства (Ю. Апресян, Н. Арутюнова, I. Левонтіна, В. Морковкін, Т. Ніколаєва, О. Уринсон).

Монографія складається з Передмови, підготовленої Т. Космедою, чотирьох розділів, Післямови авторства Т. Космеди, яка, крім того, $є$ науковим редактором цього монографічного видання. Варті уваги Списки використаної літератури, лексикографічних та ілюстративних джерел (заг. кільк. 561 од.), наскрізний Покажчик імен (334 од.), репрезентованих у монографії.

У Передмові актуалізовано теоретичні засади дискурсивної лінгвістики, iі термінологію, коротко окреслено зміст праці та ii мету і завдання. Розлогі Примітки репрезентують своєрідність вияву ДС у сучасному дискурсивному просторі функціювання української мови. 
У першому розділі «Теоретичні засади дослідження дискурсивних слів та специфіка їхнього функціювання в різних видах дискурсу» (д. філол. н., проф. Т. Космеда) описано категорійний апарат і парадигмальний простір теорії ДС, зокрема схарактеризовано «дискурсивну концепцію» О. Потебні, що вважаємо важливим екскурсом в історію ДС, оскільки «О. Потебня вказує на модальні значення слів української мови, що їх у сучасній науковій парадигмі називаємо дискурсивними, фіксуючи процес виникнення цих значень унаслідок трансформації граматичних функцій, зокрема учений наголошує, що українське буває, бува посилює значення може» (Космеда, Олексенко \& Павлова, 2019: 20). 3 наукового тексту О. Потебні виокремлено саме ті міркування, що пов'язані з особливостями зміни граматичних значень і стосуються специфіки функціювання мовних одиниць.

Майстерність маніпуляції прагматикою дискурсивних слів та виразів авторка ілюструє мовленням героїв п’єси І. Котляревського «Наталка Полтавка» (1.2.1), поетичними текстами М. Стельмаха (1.2.2), Б. Олійника, М. Вінграновського, В. Стуса, І. Драча (1.2.3), особливу увагу приділено поетичному мовленню В. Симоненка як майстра інтимізації тексту «смислами, що моделюють прагматичні ефекти, мовну гру, відображаючи індивідуальне чуттєве суто чоловіче (маскулінне) сприйняття світу...» (Космеда, Олексенко \& Павлова, 2019: 51) (1.2.4). Параметри комунікативної компетенції мовної особистості (MO) Т. Космеда простежує в «живому» мовленні I. Франка, аналізуючи фонд «дрібних» слів, наголошуючи, що «саме ці слова містять неявні смисли, які вважають особливо показовими для мовної картини світу МО» (Космеда, Олексенко \& Павлова, 2019: 52) (1.3). Проекція зазначеної методики у сферу вивчення повсякденного, наукового або фахового мовлення видатних МО, зокрема наших сучасників, висвітлює нові філіграні МО, поглиблює теорію дискурслінгвістики (1.4). ДС авторка вважає ще й потужним засобом формування соціолекту як варіанту мови, що є «об’єднувальним культурним і комунікативним знаково-символічним середовищем існування особистості» (Космеда, Олексенко \& Павлова, 2019: 69). Докладний опис ДС і виразів в урбанолекті Одеси доповнює «мовний портрет міста», що приваблює увагу численних дослідників (1.5). Розділ завершують стислі висновки, що, звісно, простежуємо після кожного розділу в рецензованій монографії. 
Другий розділ «Прагматика, семантика та функції числівника в поетичному мовленні українських шістдесятників» (к. філол. н., доц. І. Павлова) присвячений опису числівника як ДС, що розглядається крізь призму філософії мови та лінгвопрагматики. Авторка продовжує розпочаті студії в єдиному текстовому просторі поетичного мовлення шістдесятників М. Вінграновського, І. Драча, Л. Костенко, Б. Олійника, В. Стуса, визначаючи статус й окреслюючи аспекти дослідження числівника в ракурсі традиції та нових лінгвістичних парадигм (2.1).

Багатогранність дослідження створює цілісну концепцію числівника як ДС, з урахуванням його спроможності породжувати нові смисли в поетичному дискурсі, стильової мотивації його семантичних і прагматичних потужностей, а також функційних можливостей у моделюванні художніх засобів, здатністю репрезентувати поетичну картину світу шістдесятників, маркувати ідіостиль митців (2.2). Теоретично обгрунтований і досліджений на багатому практичному матеріалі статус числівника і його похідних як репрезентантів інтертекстуальності, прецедентності, автопрецедентності (2.3). Розділ щедро засіяний поетичними ілюстраціями, здійснено статистичні обрахування, що надало можливість добре обгрунтувати висновки.

Третій розділ «Числівник і його форми - маркери визначення психотипу мовної особистості: доведення гіпотези на матеріалі поетичного дискурсу шістдесятників (М. Вінграновський, I. Драч, Л. Костенко, Б. Олійник, В. Стус)», виконаний Т. Космедою та I. Павловою у співавторстві, переслідував мету «продемонструвати, що особливості актуалізації числівника та його форм можна вважати одним з маркерів належності письменника до відповідного психотипу - екстра-, інтро- чи амбівертного» (Космеда, Олексенко \& Павлова, 2019: 202). Авторки розглядають потенціал числівника як ДС для діагностики психотипу МО, визначаючи домінантні ознаки інтровертів, екстравертів та амбівертів. Оригінальність підходу надає можливість по-новому осмислити мовну творчість українських поетів-шістдесятників Л. Костенко, М. Вінграновського, І. Драча, Б. Олійника, В. Стуса в психолінгвістичному ракурсі, а сміливість наукової думки заслуговує на схвалення.

У четвертому розділі «Прагматика, семантика та функції особових і присвійних займенників як дискурсивних слів і маркерів психотипу 
мовної особистості в текстовому просторі М. Вінграновського, І. Драча, Л. Костенко, Б. Олійника» (к. філол. н., проф. О. Олексенко) обгрунтовано функції займенника як ДС, описана його «хамелеонова» вдача: здатність міняти свою семантику й прагматику, що проілюстровано на прикладах функціювання займенника в дискурсі шістдесятників, продемонстровано його лінгво- й психокатегорійний статуси. Авторка доходить висновку, що «аналіз смислових домінант, репрезентованих займенниками 1-ї та 2-ї особи в мові поетів, які належать до різних психотипів» (Космеда, Олексенко \& Павлова, 2019: 266), зокрема I. Драч, Б. Олійник - екстраверти, М. Вінграновський, Л. Костенко - інтроверти, виявив певні закономірності, а саме: “Ліричне Я” всіх поетів семантизується переважно за допомогою референта “Я особистісне"; у поетів-інтровертів виявляється тенденція до семантичного зближення "Я особистісного" з “Я уособленим", “Я зіставним” і “Я функційним”, а в екстравертів, крім “Я особистісного”, це і “Я функційне”, і “Я зіставне”, і “Я опредметнене”, і “Я ліричного персонажа” (Космеда, Олексенко \& Павлова, 2019: 266). Визначаючи специфіку інтерсуб'єктності в поетів-екстравертів, О. А. Олексенко наголошує, що цей тип взаємодії поширений не тільки в інтимній ліриці, а й у громадянській, коли часто “Я особистісне” і “Я функційне” поєднується з “ТИ конкретного співрозмовника” й “ТИ узагальненим”, породжуючи “МИ, об’єднане спільними цінностями, спільною долею”. Отже, авторці вдається показати функційну вагу займенника та його конструкцій у здатності максимально конденсувати приховані смисли й кваліфікувати їх «як дискурсивні слова, через які дешифрується семантика й прагматика дискурсу» (Космеда, Олексенко \& Павлова, 2019: 242).

Завершує працю Післямова (Т. Космеда), у якій узагальнено значення висвітленої в монографії теорії для розвитку сучасної науки, наголошено на необхідності укладання відповідних методик опису семантичної і прагматичної природи ДС, до класу яких, «крім модальних слів та виразів, вставних слів та виразів, прийменників, часток, сполучників, прислівників, слів категорії стану, деяких дієслівних форм, відносять, зокрема, числівникові й займенникові форми» (Космеда, Олексенко \& Павлова, 2019: 269); акцентовано на функційних можливостях числівникових і займенникових форм як одиниць, що «створюють зони дискурсивної статистичної напруженості, належать 
до ядерних елементів авторського тезаурусу, посідають вагоме місце в їхній МКС» (Космеда, Олексенко \& Павлова, 2019: 271); окрім того, практичним шляхом спростовано поширену в лінгвістиці думку про неспроможність числівникових і займенникових форм активно реалізувати функції художніх засобів. Окреслені перспективні напрями розвитку теорії ДС, на думку авторів, сприятимуть розвитку української дискурслінгвістики й національного мовознавства загалом.

Цілісну концепцію монографії підтримує й художнє оформлення видання, відзначимо й досконалий авторський стиль. Естетика обкладинки відтворює основні ідеї наукової праці, що зазначені на зворотній частині. Бракує хіба предметного покажчика та широкої анотації англійською мовою для популяризації української науки.

Уважаємо, що сучасна лінгвістика поповнилася ще однією вагомою й новаторською працею, що крокує в ногу з часом, розвиваючи й збагачуючи наші знання про мову.

Осіпова Тетяна Федорівна - кандидат філологічних наук, доцент кафедри української мови, Харківський національний педагогічний університет імені Г. С. Сковороди, вул. Валентинівська, 2, м. Харків, 61168, Україна.

Tel.: +38095 5500501

E-mail: : ostaniya1967@gmail.com

http://orcid.org/0000-0003-2899-2606

Osipova Tetiana Fedorivna - Ph.D in Philology, Associate Professor Ukrainian Language Department, H.S. Skovoroda Kharkiv National Pedagogical University, Valentynivska Str., 2, Kharkiv, 61168, Ukraine. 